\title{
Pemimpin Kristen sebagai Agen Perubahan di Era Milenial
}

\author{
Suhadi \\ Sekolah Tinggi Teologi Berita Hidup, Surakarta \\ Email:danielsuhadi@yahoo.co.id. \\ Yonatan Alex Arifianto \\ Sekolah Tinggi Teologi Sangkakala, Salatiga \\ Email:arifianto.alex@sttsangkakala.ac.id
}

\begin{abstract}
Real leadership begins with the person of a leader with a servant's heart, then is revealed to be outside serving others. It is Jesus who is a model role model for Christian leaders, so that Christian leaders are given the ability by God to bring about changes as God wants. Christian leaders are able to bring change for the better, more useful to God and others, because Christian leaders are agents of change in this Melenial era, who bring generations to understand new literacy and are not technology blind. This writing uses a literature research method with a descriptive qualitative approach, so that it can describe Christian leaders, by dividing the understanding of leaders specifically in Christian leadership. So that they can qualify Christian leaders and make leadership an agent of change in the ways and steps that Christian leaders take to become agents of change. Christian leadership can be a reference for advancing the millennial generation and being a role model through agents of change who can bring technology to become a necessity today
\end{abstract}

Keywords: Christian Leaders, Agents of Change, Millennial Era, Serving.

\begin{abstract}
Abstrak
Kepemimpinan yang sesungguhnya dimulai dari diri pribadi seorang pemimpin dengan hati seorang hamba, kemudian dinyatakan keluar untuk melayani orang lain. Yesuslah yang menjadi model teladan bagi pemimpin Kristen, sehingga pemimpin Kristen diberikan kemampuan oleh Allah untuk membawa perubahan sesuai yang dikehendaki oleh Allah. Pemimpin Kristen mampu membawa perubahan kearah yang lebih baik, lebih berfaidah bagi Allah dan sesamanya, karena pemimpin Kristen adalah agen perubahan di era Melenial ini, yang membawa generasi mengerti literasi baru dan tidak buta teknologi. Penulisan ini menggunakan metode penelitian pustaka dengan pendekatan kualitatif deskriptif, sehingga dapat mendeskripsikan pemimpin Kristen, dengan pembagian pengertian pemimpin secara khusus dalam kepemimpinan Kristen. Sehingga dapat mengkualifikasi pemimpin Kristen dan menjadikan kepemimpinnan adalah sebuah agen perubahan dengan cara dan langkah yang dilakukan pemimpin kristen untuk menjadi agen perubahan. Kepemimpinan Kristen dapat menjadi acuan untuk memajukan generasi milenial dan
\end{abstract}


menjadi teladan melalui agen perubahan yang dapat membawa teknologi menjadi sebuah kebutuhan masa kini.

Kata-kata Kunci: Pemimpin Kristen, Agen Perubahan, Era Milenial, Melayani.

\section{Pendahuluan}

Persoalan yang terjadi dalam dunia usaha maupun organisasi baik formal maupun non formal bahkan ada unsur gereja menjadi hal yang tidak dapat di elakkan. Permasalahan itu terjadi bagaimana kemampuan sumber daya manusia dalam kepemimpinan tidak dapat diandalkan untuk memenuhi tugas dan tanggung jawabnya. Seperti yang diungkapkan oleh Steven Andika Sulastro bahwa: keuntungan, kesuksesan yang diperoleh dalam kepemimpinan namun juga adanya kegagalan yang dialami perusahan atau organisasi dipengaruhi oleh peranan kepemimpinan. Sebab pemimpin sangatlah penting dalam mendukung perusahaan atau organisasi dan juga pemimpin merupakan otak dalam menjalankan segala hal dari sebuah organisasi yang dipimpinnya (Sularto, 2015). Terlebih problem dan persoalan yang dihadapi gereja era disrupsi sekarang ini terutama untuk sebuah organisasi yang sudah berusia di atas 75 sampai 100 tahunan adalah mengalami keadaan yang stagnansi, sebab masih kuat dalam mempertahankan tradisi. Padahal fakta dengan jelas di depan mata bahwa dunia sedang berubah dan maju dengan cepat terutama di dunia teknologi, imformatika dan digital (Ronda, 2019).

Ada yang berangapan bahwa ketika pemimpin Kristen mengikuti zaman akan disebut kepemimpinan yang dipandang secara duniawi ataupun sekuler. Namun kepemimpinan juga tentang moral yang di emban dalam memimpin, banyaknya korupsi, kolusi dan nepotisme dan hilangnya moral dalam memimpin menjadi alasan tepat bobroknya suatu usaha ataupun organisasi. Pemimpin seharusnya mempunyai nilai takut dan taat akan Tuhan supaya dapat menjadi pemipin sejati yang berdikari dengan tuntunan Tuhan. hal itu dipengaruhi Roh Kudus sebab Roh Kudus yaitu Roh Kebenaran akan memberikan pencerahan yang dapat membawa orang memahami apa yang terkandung dalam rencana Allah dalam dirinya (Arifianto, 2020a). Sebab pribadi yang bermoral mencetak pemimpin yang mampu menghormati dan menghargai karya dan pekerjaan orang lain, begitu juga pemimpin itu mampu mengakui kemampuan orang yang dipimpin sebagai sesama dan partner kerja (Sularto, 2015). Dalam era digital saat ini diharapkan pemimpin menjadi 
mentor dan fasilitator namun hal itu yang memprihatinkan sebab sebagian pemimpin perkumpulan orang percaya atau belum siap menghadapi perubahan besar dalam dunia teknologi dan informatika saat ini padahal banyak dari umat yang dipimpinnya sudah memasuki dunia digital (Ronda, 2019).

Membahas perihal kepemimpinan tidak akan pernah habis selama dunia ini masih berputar namun kepemimpinan adalah seni untuk menyakinkan dan memberikan kepastian kepada orang lain, atau dengan kata lain kepemimpinan adalah suatu proses untuk memengaruhi orang lain. Sependapat dengan hal tersebut, Richar I. Lester menyatakan bahwa: kepemimpinan suatu konsep menajemen yang garis besarnya merupakan suatu seni memengaruhi dan mengarahkan orang lain dengan cara yang bijak, smart melalui teladan, kepatuhan, kepercayaan, hormat, dan memiliki team work yang bersemangat dalam mencapai tujuan organisasi bersama.

Seorang pemimpin secara langsung merupakan figur teladan bagi mereka yang dipimpinnya. Praktisnya, karakter seorang pemimpin itu yang akan menjadi objek yang dicermati oleh orang lain. Jendral Scharzkopt, mengungkapkan bahwa: kepemimpinan yang sejati memiliki gabungan antara karakter dan strategi namun diharapkan kepemimpinan harus memiliki karakter yang baik (Suwitdi Kusumo Dilogo Soeroto, 2017, p. 51)

Gardner juga memberikan definisi kepemimpinan "Sebagai proses pengaruh atau memberi teladan sehingga melalui proses itu seorang pemimpin mendorong atau mempengaruhi sesamanya untuk dapat menuju pada tujuan yang dicapai bersama. Dan juga kepemimpinan berkembang untuk memenuhi tuntutan lingkungan global (Gardner, 1989). Jadi kepemimpinan adalah kemampuan seseorang untuk memengaruhi, mengajak, mengarahkan, mengatur, meyakinkan, dan memberdayakan yang dipimpin (orang lain) untuk mengerti, memahami terlebih menyikapi dan melaksanakan tujuan organisasi atau visi dan misi bersama sehingga semua anggota dapat digerakkan ke masa depan untuk memberikan yang terbaik bagi terwujudnya tujuan tersebut lembaga, organisasi yang dipimpin dan manfaatnya juga dapat dirasakan orang dan seluruh komunitas kepemimpinannya.

Kepemimpinan tidak lepas dengan kehidupan dalam orang percaya atau yang dikenal dengan pemimpin Kristen karena dalam peran kepemimpinana diharapkan dapat memberikan kontribusi, dan mengangkat kinerja yang baik dalam mengelolah manajemen dengan maksimal. 
Banyak karakteristik kepemimpinan dalam Alkitab yang dapat digunakan sebagai pola kepemimpinan dalam gereja (Samarenna \& Siahaan, 2019). Gereja memiliki tanggung jawab dalam menciptakan pemimpin yang berintegritas dengan menjawab situasi dan kondisi disebabkan oleh kemunduran dalam kepemimpinan saat ini, kemunduran terjadi di setiap lini, baik dalam kepemimpinan nasional maupun kepemimpinan gereja (Tambunan, 2019). Maka itu paper ini menuangkan jawaban bagi kepemimpinan Kristen sebagai agen perubahan di era milenial. Pembahasannya dibagi menjadi empat bagian yaitu pemimpin Kristen, agen Perubahan, pemimpin Kristen sebagai agen perubahan dan terakhir dampak kepemimpinan di era milenial, sehingga dengan tema tersebut dapat memberikan dampak dan manfaat bagi kepemimpinan Kristen dan gereja

\section{Metode Penelitian}

Untuk menjawab pertanyaan topik tersebut penelitian dalam artikel ini menggunakan penelitian pustaka dengan pendekatan kualitatif deskriptif (S. E. Zaluchu, 2020). Metode dalam artikel ini adalah deskripsi analitik dengan sarana melalui studi literatur, dimana penulis memberikan deskripsi tentang kepemimpinan secara umum yang telah banyak mempengaruhi pola kepemimpinan sekuler hingga sekarang serta dampaknya di era milenial. Penulis juga mendeskripsikan kepemimpinan Kristen sehingga hasil pembahasan disusun secara deskriptif dengan menganalisis sumber-sumber utama dan sumber lainnya yang berkaitan dengan pembahasan topik artikel tersebut yang sumber-sumber literatur tersebut diolah menjadi rangkaian analisis mengikuti prinsip literatur review yang dimaksud oleh Denney (S. \& Tewksbury, 2013). Penulis juga menggunakan sumber-sumber acuan yang dapat melengkapi penelitian ini yang masih dianggap menjadi sumber penunjang. Penulis menggunakan beberapa sumber tambahan artikel jurnal maupun dari bukubuku yang membahas tentang kepemimpinan yang relevan dengan tema dan topik yang dibahas dalam penulisan tersebut.

\section{Pembahasan}

\section{Pemimpin Kristen}

Pemimpin adalah orang yang bertanggung jawab untuk memastikan semua tugas yang dilakukan. Oleh karena itu pemimpin perlu mendelegasikan tugas-tugas tersebut untuk setiap orang yang dianggap memiliki beberapa kompetensi. (Tanyid, 2018). Namun untuk menjadi pemimpin 
Kristen yang pertama bukan gaya kepemimpinannnya namun pemimpin Kristen yaitu pemimpin yang ditandai secara khusus, sebab pemimpin Kristen bukan sekedar pemimpin dari orang Kristen oleh orang Kristen dan untuk orang Kristen akan tetapi pemimpin Kristen adalah pemimpin yang di dalamnya Allah pencipta langit dan bumi turut ambil bagian di dalamnya. Pemimpin Kristen terjadi bukan karena keinginan pribadi pemimpin Kristen itu sendiri namun ada kedaulatan Allah yang berkenan kepada pemimpin Kristen. Kepemimpinan Kristen adalah kepemimpinan melayani yang berasal dari teladan Yesus Kristus. Maka itu seorang pemimpin Kristen harus memiliki gaya dan paradigm dan konsep yanag benar tentang melayani dan memberi teladan hidup melalui kepemimpinannya (Siburian, 2020, pp. 198229). Meskipun kepemimpinan Kristen meliputi banyak prinsip sama seperti kepemimpinan umum, tetapi kepemimpinan Kristen punya sifat-sifat berbeda dan khusus yang harus dipahami dan dipraktekan (Saragih, 2019). “Jika Allah dalam Kristus Yesus telah memanggil orang percaya untuk mempimpin jangan biarkan apa pun merintanginya untuk menggunakan hak istimewa guna melayani Tuhan Yesus dan melayani umatNya dengan cara menggunakan karunia, kekayaan dan kesempatan yang telah Allah berikan. Pemimpin harus memiliki panggilan yang kuat,(Arifianto, 2020b) dalam dirinya untuk dapat menjadi berkat. Jika orang percaya tersebut dipilih Tuhan maka ia termasuk sekelompok orang-orang istimewa atau disebut orang-orang khusus yang telah ditunjuk Allah untuk melakukan suatu tugas yang menantang, tetapi mendatangkan kebaikan bagi dirinya dan orang lain, yakni tugas memimpin UmatNya menuju kemenangan".

Pemimpin yang dipilih Tuhan adalah seseorang tidak boleh membandingbandingkan dengan orang lain, bahwa dirinya lebih baik daripada orang lain karena panggilan atau karunia memimpin tersebut. (Suwitdi Kusumo Dilogo Soeroto, 2017, 3839). Allah akan menumbuhkan pemimpin Kristen dan melakukan intervensi ke dalam hidup mereka untuk mengembangkan kemampuan mereka bagi maksud dan tujuantujuanNya. Allah memanggil mereka untuk menjadi pengikut-Nya, untuk memengaruhi orang lain yang dibawa dalam pengenalan akan Allah yang benar, sehingga mereka dipakai sebagai alat-alatNya. Saat Kristus memanggil pemimpin Kristen ke dalam pelayanan, Kristus ingin mengembangkan pemimpin Kristen sampai mencapai 
kepenuhan pontensi mereka. Setiap pemimpin Kristen bertanggungjawab mengembangkan potensi maksimalnya dalam proses pembentukan Allah dalam hidup pemimpin Kristen (Clinton J. Robert, 2004, 158).

Inilah yang membedakan pemimpin Kristen dengan pemimpin-pemimpin pada umumnya yang sekuler. Pemimpin Kristen berpikir, berkata, bertindak dalam kepemimpinannya bukan atas dasar kemauannya sendiri yang muncul dari kemanusiaannya, namun muncul dan berasal dari Allah yang memberikan otoritas atas kemauanNya, untuk menjalankan visi dan misi Allah serta diharapkan membawa perubahan yang berguna bagi orang Kristen dan bagi dunia ini. Berikut uraian mengenai pemimpin Kristen yang diawali dengan pengertian pemimpin secara umum, pengertian pemimpin secara khusus yaitu kepemimpinan Kristen dan kualifikasi pemimpin Kristen. Zaluchu mengatakan bahwa: Seorang pemimpin tidak dilahirkan tetapi dibentuk. Tuhan menggunakan sejumlah ujian untuk pembentukan para pemimpin. Tujuannya, selain membekali, ujian dapat memurnikan panggilan, melatih keterampilan dan membuat para pemimpin bergantung pada Tuhan. Kepemimpinan Kristen adalah bagaimana seseorang yang dipilih wajib membawa dirinya untuk bergantung kepada otoritas yang memanggilNya (S. Zaluchu, 2018).

\section{Pengertian Pemimpin secara khusus dalam kepemimpinan Kristen.}

Kenneth O. Ganggel menyatakan kepemimpinan adalah "tindakan seseorang yang muncul dari kelompok dan memiliki kualitas kepemimpinan, karakter dan kapabilitas yang bertujuan untuk menghasilkan dan juga mengubah prilaku dan kebiasaan komunitasnya menuju sasaran yang dapat diterima secara bersama (Gangel, 1970, 121). Ken Blanchard juga menyatakan bahwa: Kepemimpinan yang sesungguhnya dimulai dari dalam diri pribadi seorang pemimpin dengan hati seorang hamba, serta pemimpin dapat menjadi berkat bagi orang lain dalam melayani (Blanchard et al., 2003, 23). Tomatala juga menyatakan bahwa: kepemimpinan Kristen ialah “ kepemimpinan yang dilakukan dengan proses terencana yang dinamis dalam market place pelayanan gereja atau organisasi Kristen lainnya (yang menyangkut faktor waktu, tempat, dan siatuasi khusus) yang di dalamnya oleh rencana Tuhan dalam proses panggilannya sebagai pemimpin. Pemimpin yang diperlengkapi dengan kapasitas penuh untuk memimpin umatNya dalam pengelompokan 
diri sebagai suatu institusi atau organisasi bertujuan mencapai visi dan misi Tuhan sehingga berdampak dan menjadi berkat bagi orang yang dipimpinnya (Y. Tomatala, 2006, p. 43). Lebih lanjut Tomatala menegaskan dalam pemahanan kepemimpinan Kristen tersebut ada 6 bagian penting yaitu:

Pertama, kepemimpinan Kristen adalah proses terencana dan dinamis. Pre suposisi yang penting dalam kepemipinan Kristen ialah "Allah yang berinisiatif dan campur tangan Tuhan dalam pribadinya. yang kedua, kepemimpinan Kristen memiliki "konteks pelayanan" sebagai faktor situasi yang berhubungana dengan nilai dan bagianbagianan unsur, waktu, tempat, dan situasi khusus dalam konteks hidup yang berbeda, yang memberikan nilai plus dan pelanan itu didedikasikan sebagai bagian dari kepemimpinan hamba yang melayani.

Ketiga, kepemimpinan Kristen memiliki pre suposisi yang berkenaan dengan anugerah khusus yang menitik beratkan bahwa Allah dalam hak preogratifNya memilih pemimpin Kristen bagi diriNya yaitu pemimpin yang berkapasitas (memiliki karunia kepemimpinan, pengetahuan, keahlian serta karakter yang dapat diterapkannya bagi tugas pelayanan sebagai pemimpin dalam semua kategori).
Keempat, dalam kepemimpinan Kristen, umat Allah sebagai orang yang dipimpin mempunyai valeu tanggungjawab integral untuk secara bersama terlibat palayanana yang dikerjakan. Kelima, dalam kepemimpinan Kristen, tujuan Allah adalah dasar utama (yang menjelaskan untuk apa gereja atau orang percaya ada) yang di atasnya tujuan umat Allah (sebagai suatu kelompok, gereja, institusi atau organisasi) dibangun.

Keenam, kerajaan Allah adalah tujuan utopi bagi dan dari eksistensi serta tujuan hidup umat-Nya (gereja). Tujuan utopi (tertinggi atau teragung) difokuskan kepada Allah, dimana hal ini harus diwujudkan dalam hakikat hidup bakti umatNya yang akan ditandai oleh tekad taat kepada Tuhan, yang membawa kemuliaan bagi NamaNya.

Jadi dapat dipahami bahwa kepemimpinan Kristen ialah Suatu proses terencana yang dinamis dalam konteks pelayanan Kristen yang di dalamnya ada keterlibatan Tuhan dalam memanggil pemimpin dengan memperlengkapi dengan kapasitas penuh untuk memimpin (memengaruhi, membawa, mengembangkan, memberdayakan seluruh potensi kemampuan penuh) umatNya dalam komunitas diri sebagai suatu organisasi guna mencapai tujuan Tuhan, untuk kejayaan kerajaanNya 
(Y. Tomatala, 2006).

\section{Kualifikasi Pemimpin Kristen}

Dalam kepemimpinan organisasi memerlukan pribadi-pribadi yang memiliki wawasan luas dan kepribadian yang baik sehingga dapat membawa arah kepemimpinan organisasi tersebut kearah yang diharapkan. Dalam memilih pemimpin, banyak persyaratan yang harus dimilikinya. Persyaratan-persyaratan yang berupa skill atau keterampilan, kognitif serta kemampuan dalam wawasan luas, kecerdasan intelektual, kemampuan melihat masa depan, kemampuan melihat peluang dan persyaratan-persyaratan yang bersifat pribadi; jujur, adil, memiliki nama baik dan masih banyak persyaratan yang lain yang dibutuhkan oleh seorang pemimpin. Memang pemimpin haraus memiliki banyak kualifikasi yang menunjukkan sebagai kapasitasnya sebagai pemimpin.

Pemimpin juga mampu melihat gambaran besar, mampu mengendalikan stress dan selalu menampilkan semangat yang positif dengan memahami orang lain dan bebas dari masalah-masalah pribadi. Memiliki kemauan untuk mengambil resiko. Dalam karakternya, pemimpin juga seharusnya bukan seorang pemarah. Terlebih pemimpin Kristen juga diharapkan memiliki kemauan untuk melakukan perubahan hidup dalam integritas. Bertumbuh di dalam Tuhan, mampu melihat apa yang harus dikerjakan ke depan. Diakui oleh orang lain sebagai pemimpin. Kemauan dan kemampuan untuk terus belajar serta juga memiliki kemampuan untuk menarik orang lain kepadanya. Memiliki penilaian yang baik terhadap diri sendiri, kemauan untuk melayani orang lain. Pemimpin Kristen juga diharapkan mampu mencegah masalah, terlebih mampu mengembangkan pemimpin yang potensial dan kemauan serta kemampuan dalam mengambil inisiatif (Jhon Maxwell, 1999). Terlebih kepemimpinan Kristen juga memiliki kepemimpinan hamba, yang sangat dibutuhkan gereja, ia mutlak harus belajar dengan rendah hati dari Tuhan sendiri (Jokiman, 2018).

Dalam definisi operasionalnya mengenai kepemimpinan pribadi Robert Clinton mengungkapkan tentang seorang pemimpin sebagai berikut: seorang pemimpin, sebagaimana dirumuskan dari sebuah studi kepemimpinan Alkitabiah, ada empat hal yang sangat menarik untuk dipelajari; pertama, kepemimpinan, yang tertuju kepada personal pribadi harus memiliki kapasitas dari Tuhan, yang dimaksudkan dengan kapasitas Tuhan adalah talenta-karunia rohani dan bakat atau keterampilan alami. Kedua, Menerima 
tanggungjawab dari Tuhan, mencakup bukan hanya beban sebuah pelayanan, melainkan juga merupakan tanggungjawab yang disadari kepada Tuhan atas pelayanan tersebut. Ketiga. sebuah kelompok yang spesifik dari Tuhan. Dan keempat, Menuju kepada tujuan-tujuan Allah bagi kelompok tersebut (Clinton J. Robert, 2004).

Apa yang disampaikan Robert Clinton, dipertegas oleh Tomatala dalam uraiannya sebagai berikut: Satu, pemimpin Kristen adalah orang yang percaya dan seorang yang telah ditebus Allah, dan memastikan dengan yakin bahwa ia terpanggil oleh Allah untuk tanggungjawab atas panggilannya tersebut. Yakni memimpin suatu komunitas orang percaya. Dua, dasarfilosifis yang harus dipahami dan harus ada pada seorang Kristen bahwa ia terpanggil sebagai "pelayanan hamba". Pemimpin Kristen diharapkan mempunyai semangat "membangun hubungan dan memprioritaskan dedikasinya dalam menekankan bahwa kerja adalah fokus yang harus diprioritas, sikap utama. Tiga, pemimpin Kristen harus memahami proses kepemimpinan dan keterampilan memimpin antara lain; mengetahui tujuan, mengenal tanggung jawab, memahami dan mengenal pengelolahan kerja, mengenal setiap orang yang dipimpinnya serta mengerti dengan baik bagaimana caranya menciptakan hubungan (Yakob Tomatala, 2003, 47-49).

Bila melihat dalam Alkitab dalam Perjanjian Baru secara khusus di kitab surat penggembalaan yaitu surat Timotius dan surat Titus. Dalam kitab tersebut mensyaratkan sebagai seorang pemimpin atau penatua atau pemimpin jemaat antara lain : (1Tim 3:1-7) syarat-syarat bagi Penilik Jemaat adalah (1Tim 3:2) harus pribadi yang tak bercacat (1Tim 3:2) seseorang yang dapat menahan diri (1Tim 3:2) hidup bijaksana, (1Tim 3:2) pribadi yang sopan (1Tim 3:2) suka memberi tumpangan hidup murah hati (1Tim 3:2) seorang yang cakap mengajar (1Tim 3:3) tidak bercelah dan ia seorang yang bukan peminum (1Tim 3:3) ia bukan pemarah (1Tim 3:3) namun ia seorang yang peramah (1Tim 3:3) suka damai dan menjadi pendamai (1Tim 3:3) bukan cinta uang atau hamba uang (1Tim 3:7) seseorang yang mempunyai nama baik (1Tim 3:6). Diharapkan tidak orang yang baru bertobat. Dalam keluarga ada pedoman dan tuntunan yang harus dipenuhi seorang pemimpin (1Tim 3:2) ia seorang suami dari satu istri saja (1Tim 3:4-5) yang memiliki integritas seorang kepala keluarga yang baik (1Tim 3:4) disegani dan dihormati oleh anak-anaknya (Suhadi \& Buffet, 2008, p. 54) Sedangkan untuk kepemimpinan dalam 1Tim 3:8-12 secara khusus syarat- 
syarat bagi diaken harus memiliki kualifikasi pribadi (1Tim 3:8) yaitu harus orang yang hidup terhormat (1Tim 3:8) seorang yang tidak bercabang lidah (1Tim 3:8) tidak penggemar anggur atau pemabuk (1Tim 3:8) tidak hidup dalam keserakahan (1Tim 3:9) seorang yang berani memelihara rahasia iman dalam hati nurani yang suci. (1Tim 3:10) dapat diiuji dan mempunyai nilai karakter yang tak bercacat. Dalam keluarga juga dapat dituntut sebagai bagian dari kepemimpininan itu. (1Tim 3:12) suami dari satu istri (1Tim 3:11) istri adalah juga orang terhormat dan dapat (1Tim 3:12) mengurus anak-anak dan keluarga dengan baik (Suhadi \& Buffet, 2008)

Jadi kualifiskasi kepemimpinan adalah memiliki kepribadian yang tak bercacat, dapat menahan diri, bijaksana, sopan, suka memberi tumpangan, cakap mengajar, bukan peminum, bukan pemarah, namun peramah, pendamai, bukan hamba uang. juga mempunyai nama baik. Terlebih bukan orang yang baru bertobat. Untuk keluarga juga memiliki intergritas suami dari satu istri, kepala keluarga yang baik, disegani dan dihormati oleh anak-anaknya, serta hidup dalam tuntunan Roh Kudus sebagai pribadi yang mengajar dan menuntun,(Arifianto \& sumiwi Rachmani, 2020) personal dan kepemimpinannya.
Kepemimpinnan adalah sebuah agen perubahan

Seorang penasihat gereja yang dihormati, Lyle Schaller, pernah mengatakan jika seorang pemimpin Kristen (Pendeta) tidak memiliki hasrat untuk menjalankan misi pelayanan, pemimpin Kristen itu dapat melupakan sisa kepemimpinan berikutnya. Hasrat untuk membuat perubahan yang berharga menuju pada kebaikan dan kesempurnaan sangat diperlukan bagi suatu efektivitas kepemimpian Kristen. Hasrat atau kemauan dan visi perlu bekerja sama. Kerinduan untuk memberikan seluruh potensi dan kemampuan pemimpin Kristen pada visi dan misi dengan mendisiplinkan keinginan atau hasrat. Semakin jelas visinya, semakin besar hasratnya, semakin mendekat pada capaian tujuannya (Fred Smith, SR, 2002, 77).

Pemimpin Kristen, adalah status yang diharapkan tetapi juga tidak diinginkan oleh beberapa orang. Karena kepemimpinannnya bukanlah apriori terhadap tanggung jawab yang di embannya, melainkan pola pikir dan persyaratan moral serta kerohanian yang terlalu tinggi untuk menjadi pemimpin Kristen (Pranoto, 2011). Pemimpin Kristen wajib menjadi agen perubahan yang membawa pembaharuan seseorang menjadi lebih berguna atau berfaedah. Pandangan 
umum menyatakan bahwa suatu tempat dimana untuk melakukan berbagai kegiatan untuk membawa pembaharuan dari yang kurang baik menjadi suatu yang baik. Sementara kata agen sendiri menurut Kamus Besar Bahasa Indonesia, adalah orang atau perusahaan perantara yang mengusahakan penjualan bagi perusahaan lain atas nama pengusaha; perwakilan (Suharso \& Retnoningsih, 2005, p. 19). Sedangkan perubahan berasal kata dasar ubah yang memiliki arti "menjadi lain ( berbeda) dari semula; bertukar, (beralih, berganti) menjadi sesuatu yang lain (Suharso \& Retnoningsih, 2005). Berdasarkan pengertian kedua arti itu jika digabungkan maka akan muncul orang atau perusahaan sebagai tempat atau wahana untuk membawa pembaharuan yang beralih dari semula. Makna agen perubahan menurut Burt Nanus menyatakan bahwa: nilai kepemipinan yang efektif harus terus menerus menyesuaikan terhadap perubahan yang terjadi dan berpikir menuju visi dan misi sebagai sikap perubahan potensial untuk kemajuan (Nanus, 1992).

Pemimpin adalah agen perubahan, dan juga pemimpin adalah pribadi yang secara sadar bertanggung jawab untuk merekontruksi system dan tingkah laku anggota yang di pimpinnya. Namun Lewin dan Schein berpendapat bahwa supaya mengalami perubahan yang menjadikan sukses dalam organisasi yaitu: keinginan untuk berubah (desire of change), sebelum perubahan terjadi setiap individu harus merasakan suatu kebutuhan, dapat berupa kekurangan-kekurangan dan ketidakpuasan selama ini serta adanya keinginan untuk meningkatkan (Kahar, 2008).

Peran agen perubahan adalah sebagai bentuk atau upaya banyak hal yang membawa sesuatu dapat mengubah identitas dan karakter sehingga menjadi lebih berarti dan bermakna. Kepemimpinan yang sesuai dengan kebutuhan akan anggotanya dengan tujuan mampu membawa anggotanya mencapai tujuan suatu organisasi (Daswati, 2012). Sehingga seorang agen perubahan hidup untuk di masa depan dan bukan sekarang. Terlepas dari apa yang sedang terjadi saat ini, agen perubahan memiliki visi tentang apa yang bisa atau seharusnya dilakukan sebagai pemimpin. Seorang agen perubahan didorong oleh semangat yang menginspirasi banyak orang atau setidaknya orang yang dipimpinnya. Terlebih seorang agen perubahan memiliki kemampuan yang kuat untuk memotivasi diri. Akhirnya yang harus dimiliki pemimpin adalah seorang agen perubahan harus memahami orang dan juga dapat dinyatakan sebagai pemimpin yang 
menjadi teladan bagi semua orang (Tari et al., 2019).

Dalam pelayanan maupun dalam organisasi bahwa kepemimpinan Kristen sebagai agen perubahan menjadi kunci dari sebuah keberhasilan dan perubahan besar dalam organisasi. Jika pemimpin Kristen berani menyampaikan kepemimpinananya dengan cerdas dan menginspirasi, bagi perubahan dengan tujuan membangun manajemen maupun sebuah pelayanan yang solid dan kuat di dalam organisasinya, maka semua orang yang ada dalam kepemimpinannya dan semua unit kerja maupun pelayanan dapat termotivasi untuk bergerak menjadi kuat dan besar terlebih menjadi lebih bersemangat dengan etos kerja dalam etos dan etika bekerja. Hal itu memang harus belajar dan meneladani dari pribadi Agung Yesus sebagai pemimpin yang mampu memberikan perubahan menuju kebaikan dan membawa dampak besar bagi setiap pribadi yang ditemuinya. Tidak dapat dipungkiri bahwa Yesus Kristus, agen perubahan yang besar bagi umat manusia. Yesus menginginkan orang percaya untuk mengasihi satu sama lain sebagai orang yang siap dengan masa depan.

Yesus mengubah kehidupan dua belas pria dari Israel, Yesus memilih pribadipribadi menjadi murid-Nya juga memperlengkapi dan mempersiapkan mereka menjadi pemimpin besar. Yesus sebagai teladan yang perlu dicontoh dengan menawarkan solusi Ilahi dalam setiap kepemimpinannya. Hal itu terjadi saat perubahan hukum yang disampaikan Yesus bahwa Kasih adalah hukum yang pertama dan menjadi hukum yang utama. Yesus juga membawa perubahan terhadap seorang wanita pezinah di sumur dan seorang wanita tertangkap dalam perzinahan sebagaimana Yesus menawarkan solusi bagi mereka pengampunan dan hidup baru. Yesus juga mengubah kehidupan seorang pria bernama Paulus.

Perubahan bagi dunia dan umat manusia terlebih diawalai oleh Yesus dalam pelayanannya mendedikasikan kepada tujuan penyelamatan manusia. Ia taat dan bersedia menyerahkan nyawaNya untuk menyelamatkan manusia. Sekarang seluruh dunia berubah karena apa yang telah dilakukan Yesus. bahkan dalam pelayananNya Ia rela untuk melayani sebagai seorang hamba yang tunduk dan taat agar melalui pengorbananNya menyelamatkan seluruh manusia yang percaya kepadaNya (Djadi \& Thomassoyan, 2011). Karena Pribadi Yesus adalah pribadi yang patut menjadi contoh dan sentral hidup dan teladan bagi orang percaya terlebih keteladanan 
kepemimpinan-Nya masih relevan untuk diterapkan dalam kepemimpinan Kristen bahkan tetap berdampak dengan kepemimpinan Kristen pada masa kini sebab ada keterlibatan Tuhan (Katarina \& Siswanto, 2018).

Kepemimpinan yang sesungguhnya dimulai dari Panggulan Tuhan dan diri pribadi seorang pemimpin yang memiliki hati seorang hamba, kemudian dapat menjadi berkat bagi orang diluar dengan landasan melayani orang lain. Oleh karena itu, (agent of change) yang mempunyai peran dan tanggungjawab untuk mengupayakan dan merekontruksi pola perubahan dalam komunitas internal sehingga ada dampak perubahan. Pemimpin harusnya memainkan tanggung jawab dan peran yang sangat dominan dalam kehidupan komunitas. Namun peranan tersebut tidak mengurangi sebagai pemimpin untuk terus membina dan terus mengarahkan anggot bagi kepentingan organisasi. Dan juga diperlukan telaah terhadap kepemimpinan Kristen yang diterapkan dan dipahami sebagai bidang studi lintas disiplin yang berpedoman pada kedua disiplin ilmu teologis dan lainnya (Kessler \& Kretzschmar, 2015). Oleh sebab itu diperlukan pemimpin Kristen yang menguasai dan menggunakan teknologi, informatika dan era digital baik secara media sosial maupun literasi dapat digunakan sebagai bagian agen perubahan di era milenial.

Di generasi milennial yang merupakan kelompok dari generasi digital memiliki sebuah pengertian yang pada saat ini menjadi suatu hal yang fenomenal dan seringkali dibicarakan oleh banyak orang (Mutia, 2017). Generasi yang menselaraskan kehidupan untuk dapat diaplikatifkan dalam bentuk bertransformas dengan kehidupan sosial sebagai aspek yang penting. Terlebih media sosial menjadi sarana yang mendominasi kemajuan teknologi dalam berkomunikasi yang cepat. Pribadi generasi milenial juga berperilaku konsumtif. Karakteristik dasar generasi era milenial adalah gampang bosan dan menggantungkan pada akses internet tak terbatas. Generasi ini mengharapkan berselancar dengan bebas melalui gadgetnya. Generasi milienal adalah suatu kelompok demografi setelah generasi $\mathrm{X}$ yang lahir pada awal 1980-an dan pertengahan tahun 1990-an dan berakhir pada tahun 2000-an. Masyarakat era milenial terkadang disebut sebagai "Echo Boomers" karena adanya 'booming' (peningkatan besar) tingkat kelahiran di tahun 1980-an dan 1990an. Generasi ini memiliki karakter; pertama sebagai User Generated Content (UGC) lebih dipercaya oleh kaum milenial ketimbang 
informasi satu arah, dan hal itu perlu diketahui bahwa generasi milenial ini juga memiliki akun pribadi sosial media sebagai alat komunikasi dan pusat informasi; serta memiliki minat membaca secara konvensional kini sudah menurun karena lebih memilih membaca lewat smartphone; dan terakhir memilih gadget handphone daripada aneka macam siaran TV, dikarenakan menonton tayangan televisi bukan lagi menjadi sebagai hiburan sebab segala apapun bisa mereka temukan di gadget smartphone. Dalam menghadapi generasi ini, pemimpin Kristen diharapkan untuk mampu dalam penguasaan ilmu dan teknologi yang senantiasa mengikuti kemajuan zaman (Rifai, 2018)

\section{Langkah-Langkah Pemimpin Kristen membawa Perubahan.}

Langkah Pertama: membawa pada Pemahaman Literasi

Pemimpin Kristen harus mampu membawa perubahan pemahaman pada literasi. Dalam era milenial dan dunia digital dan kecepatan teknologi informasi pemimpin Kristen memiliki peran yang mau ambil andil dalam kemajuan pengembangan melalui literasi. Untuk dapat memahami literasi baru tidak bisa lepas dari literasi yang telah ada sebelumnya atau yang literasi lama yang pada esensinya tidak bisa keluar dari tiga pilar literasi, yaitu membaca, menulis, dan mengarsipkan. Jika dihubungkan dengan literasi, semua ini tidak bisa lepas dari peran lembaga pendidikan terutama pendidikan dalam gereja yang dikerjakan lewat teknologi informasi. Pemimpin Kristen harus berperan aktif di era melenial yang membawa dampak perubahan dalam menuju pada literasi baru. Pemimpin Kristen, perlu landasan dan konsep yang harus dilakukan untuk mebiasakan kepada generasi milenia dan mengenalkan literasi baru dalam berbagai bentuk kajian penulisan.

Langkah Kedua: Pemimpin Kristen harus mampu menuangkan gagasan baru dalam bentuk tulisan.

Dalam mengembangkan konsep kepemimpinannya, pemimpin Kristen perlu menuangkan semua ide, gagasan dan pemikirannya yang terungkap, dalam bentuk tulisan. Pemimpin Kristen harus menuliskan semua gagasannya dalam bentuk tulisan, yang dapat dibaca dan dimengerti dengan benar serta dipahami oleh orang percaya dalam bimbingan kepemimpinannya atau juga dapat menjadi kesaksian bagi gereja dan orang diluar gereja yaitu masyarakat Kristen pada khususnya dan secara umum adalah masyarakat luas. Tulisan akan menjadi arsip 
dan dokumen penting, demi kepentingan generasi generasi berikutnya.

\section{Langkah yang ketiga: Pemimpin} Kristen wajib mendokumentasikan karyanya dalam bentuk Pengarsipan.

Di era milenial ini, pemimpin tidak cukup hanya pandai bicara, atau beretorika namun juga harus pandai menuangkan gagasan dan ide dalam tulisan dan mengarsipkannya menjadi sebuah karya yang dapat dimengerti oleh khalayak orang. Pusat tujuan dari literasi teknologi adalah pengembangan ilmu pengetahuan. Penerapan pilar literasi dari konvensional menuju digital dengan membuka wawasan dalam membaca, menulis, dan menyebarkan informasi. Seorang pemimpin Kristen terus dapat mengupayakan pengembangan diri sehingga mampu menguasai kemajuan teknologi. Kemajuan teknologi dikembangkan adalah bagian yang positif untuk membangun budaya dan adab manusia, yang semakin berkenan kepad Tuhan Yesus. Jangan malah sebaliknya pemimpin Kristen terlindas oleh kemajuan teknologi sehingga terbawa arus kepada hal-hal yang negatif. Pemimpin Kristen harus mampu menjadi agen perubahan yang membawa dampak positif, apapun kondisi perubahan dunia. Dunia setiap saat berubah, mau tidak mau harus mengikuti perkembangannya namun jangan ada pemimpin Kristen tenggelam dalam perubahan dunia yang negatif

Langkah yang keempat adalah pemimpin Kristen harus berani membawa karakter Kristen yaitu kebenaran Kristus.

Justru Pemimpin Kristen berani membawa perubahan menuju kepada kebenaran yang diperkenan oleh Yesus Kristus. Dalam mengungkapkan literasi juga menjadi literasi data dan penggunaan digital teknologi. Literasi sumber daya manusia (SDM), adalah literasi yang manusialah yang menentukan perubahan. Karena pemimpin juga harus memberi kesiapan kepada manusia untuk bersaing, menggunakan pendekatan integritas dalam memanfaatkan kemajuan teknologi, menggunakan pendekatan azas manfaat dalam menghadapi disrupsi teknologi, dan melakukan pendekatan yang humanistik (Ronda, 2019). Sebab organisasiorganisasi yang begerak dalam lingkup akademik ataupun organisasi yang bersifat kemasyarakatan harus menyambut era melinial yang juga yang dimaksud sebagai era Revolusi Industri 4.0. Namun dasar acuan pengembangan kemajuan dunia informasi dan teknologi supaya teknologi tidak tercerabut dari nilai-nilai kemanusiaan, (Prasetyo Banu \& Trisyanti, 2018). Maka itu harus mencetak generasi yang paham literasi data dan literasi teknologi. Karena sumber 
daya manusia yang dihasilkan dapat bersaing dan berkontribusi secara global melalui kajian literature yang dihasilkan (Lase, 2019). Artinya bahwa setiap organisasi harus mencetak generasi yang dapat memahami di bidang literasi data maupun literasi teknologi. Dalam ranah akademik, dibidang kesehatan dan juga organisasi-organisasi kemasyarakatan. Jika jaman sekarang adalah era cyber, era digital, maka kompetensi generasi tidak lagi manual, gaya kuno apalagi gaya primitive. Untuk itulah diperlukan peranan pemimpin Kristen, untuk terus mencetak generasi yang memahami literasi dan tidak buta teknologi, yang dapat menjadi acuan bagi kemajuan zaman. Sehingga membuka opportunity bagi sumber daya manusia dalam berperan aktif memiliki skill yang sesuai dengan perkembangan kemajuan digital teknologi terkini. Untuk itu, diperlukan pelaksanaan program peningkatan keterampilan (up-skilling) atau pembaruan keterampilan (re-skilling) para sumber daya manusia berdasarkan kebutuhan dunia industri saat ini (Rohida, 2018).

\section{Kesimpulan}

Kepemimpinan adalah kemampuan seseorang untuk memengaruhi, mengajak, mengarahkan, mengatur, meyakinkan, dan memberdayakan orang dalam kepemimpinan dan juga untuk mengerti, memahami, menyikapi dan melaksanakan visi dan misi secara kooperatif sehingga seluruh anggota digerakkan ke masa depan yang lebih baik. Namun kepemimpinan Kristen ialah suatu proses terencana yang sangat dinamis dalam ranah pelayanan Kristen yang didalamnya ada keterlibatan Tuhan, sebab Tuhan memanggil bagi diriNya seorang pemimpin dengan kapasitas penuh untuk memimpin (memengaruhi, membawa, mengembangkan, memberdayakan seluruh potensi kemampuan penuh) umatNya dalam kesatuan diri sebagai suatu organisasi guna mencapai tujuan Allah, untuk kejayaan kerajaanNya

Maka itu dapat disimpulkan bahwa pemimpin secara khusus dalam kepemimpinan Kristen dapat memberikan jawaban dan pemahaman, bagaimana mengkualifikasi pemimpin Kristen dan kepemimpinan Kristen adalah sebuah agen perubahan dengan cara dan langkah yang dilakukan sebagaimana pemimpin kristen untuk menjadi agen perubahan. Pemimpin Kristen mampu membawa perubahan ke arah yang lebih baik, lebih berfaedah bagi sesama dan memuliakan Tuhan.

\section{Daftar Pustaka}

Arifianto, Y. A. (2020a). Pentingnya

Pendidikan Kristen dalam Membangun 
Kerohanian Keluarga di Masa Pandemi Covid-19. REGULA FIDEI: Jurnal Pendidikan Agama Kristen, 5(2), 94106.

Arifianto, Y. A. (2020b). Peran Gembala Menanamkan Nilai Kerukunan dalam Masyarakat Majemuk. Voice Of Hamy Jurnal Teologi Dan Pendidikan Agama Kristen, 3(1), 1-13.

Arifianto, Y. A., \& sumiwi Rachmani, A. (2020). Peran Roh Kudus dalam Menuntun Orang Percaya kepada Seluruh Kebenaran Berdasarkan Yohanes 16 : 13. Jurnal Diegesis, 3(1), $1-12$.

Blanchard, K., Ross, P. H. L., \& Wills., A. (2003). Beginning The Journey Lead Like JESUS ( Memulai Perjanalanan: Memimpin seperti Yesus mengubah hati, pikiran, perilaku serta kebiasaan anda. STT Baptis Indonesia.

Clinton J. Robert. (2004). Pembentukan Pemimpin sejati, menenali pelajaranpelajaran dan langkah-langkah Pengembangan Pemimpin. Church Resource Ministri (CRM).

Daswati. (2012). Implementasi peran kepemimpinan dengan gaya kepemimpinan menuju kesuksesan organisasi. Academica Fisip Untad. Djadi, J., \& Thomassoyan, Y. C. (2011).
Kepemimpinan Yesus Kristus Menurut Injil Sinoptik Dan Relevansinya Terhadap Kepemimpinan Rohani Masa Kini. Jurnal Jaffray. https://doi.org/10.25278/jj.v9i1.091.6085

Fred Smith, SR. (2002). Memimpin dengan Integritas dilengkapi dengan karakter Kristen. Leading With Integrity. penerbit Yayasan Pekabaran Injil Imanuel.

Gangel, K. O. (1970). Leadership for Church Education. Moody press. Gardner, J. W. (1989). The Changing Nature of Leadership. NASSP Bulletin. https://doi.org/10.1177/0192636589073 51714

Jokiman, B. (2018). Dasar-Dasar Alkitabiah Pengembangan Kepemimpinan. Veritas : Jurnal Teologi Dan Pelayanan. https://doi.org/10.36421/veritas.v4i1.10 2

Kahar, I. A. (2008). Konsep Kepemimpinan dalam Perubahan Organisasi (Organizational Change) pada Perpustakaan Perguruan Tinggi. Pustaha: Jurnal Studi Perpustakaan Dan Informas, 4(1), 21-27. Katarina, K., \& Siswanto, K. (2018). Keteladanan Kepemimpinan Yesus Dan 
Implikasinya Bagi Kepemimpinan

Gereja Pada Masa Kini. Evangelikal:

Jurnal Teologi Injili Dan Pembinaan

Warga Jemaat.

https://doi.org/10.46445/ejti.v2i2.102

Kessler, V., \& Kretzschmar, L. (2015).

Christian leadership as a transdisciplinary field of study. Verbum et Ecclesia. https://doi.org/10.4102/ve.v36i1.1334

Lase, D. (2019). Pendidikan di Era Revolusi Industri 4.0. SUNDERMANN: Jurnal Ilmiah Teologi, Pendidikan, Sains, Humaniora Dan Kebudayaan. https://doi.org/10.36588/sundermann.v1 i1.18

Maxwell, J. C., \& Publishers, T. N. (1999).

The 21 Indispensable Qualities of a Leader Take-Aways.

Mutia, T. (2017). Generasi Milenial, Instagram Dan Dramaturgi: Suatu Fenomena Dalam Pengelolaan Kesan Ditinjau Dari Perspektif Komunikasi Islam. An-Nida'.

Nanus, B. (1992). Visionary Leadership: How to Re-Vision the Future. The Futurist.

Pranoto, D. (2011). PERAN ROH KUDUS DALAM SPIRITUAL FORMATION PROCESS BAGI MAHASISWA KRISTEN SEBAGAI CALON
PEMIMPIN. Jurnal Antusias.

Prasetyo Banu, \& Trisyanti, U. (2018).

REVOLUSI INDUSTRI 4.0 DAN

TANTANGAN PERUBAHAN

SOSIAL. IPTEK Journal of

Proceedings Series, 5.

Rifai, M. H. (2018). Mengenal Generasi

Milineal Guna Kesiapan Tenaga

Pendidik Dan Dosen Di Indonesia.

Pendidikan Dan Pembelajaran.

Rohida, L. (2018). Pengaruh Era Revolusi

Industri 4.0 terhadap Kompetensi

Sumber Daya Manusia. Jurnal

Manajemen Dan Bisnis Indonesia.

https://doi.org/10.31843/jmbi.v6i1.187

Ronda, D. (2019). Kepemimpinan Kristen

Di Era Disrupsi Teknologi.

Evangelikal: Jurnal Teologi Injili Dan

Pembinaan Warga Jemaat, 3(1), 1.

https://doi.org/10.46445/ejti.v3i1.125

S., D. A., \& Tewksbury, R. (2013). "How to Write a Literature Review,." Journal of Criminal Justice Education, 24(2), 218-234.

Samarenna, D., \& Siahaan, H. E. R. (2019).

Memahami dan Menerapkan Prinsip

Kepemimpinan Orang Muda Menurut 1

Timotius 4:12 bagi Mahasiswa Teologi.

BIA': Jurnal Teologi Dan Pendidikan

Kristen Kontekstual.

https://doi.org/10.34307/b.v2i1.60 
Saragih, D. R. P. (2019). IMPLEMENTASI KEPEMIMPINAN KRISTEN. Voice of Wesley: Jurnal Ilmiah Musik Dan Agama.

https://doi.org/10.36972/jvow.v2i2.27

Siburian, H. H. (2020). Pentingnya Model Kepemimpinan Dalam Pendidikan Kristen Masa Kini. In Sam Soukotta Sang Pemimpin Karakter Kristen (pp. 198-229). https://doi.org/10.31219/osf.io/ujk3r

Suhadi, D., \& Buffet, Y. (2008). Pembimbing ke Dalam Perjanjian Baru. STT Berita Hidup Surakarta. Suharso, \& Retnoningsih, A. (2005). Kamus Besar Bahasa Indonesia edisi lux. CV. Widya karya.

Sularto, S. A. (2015). KEPEMIMPINAN MORAL KRISTEN PADA CV BERKAT ANUGRAH LESTARI, SIDOARJO. Agora, Jurnal Mahasiswa Manajemen Bisnis, 3(2), 645-649.

Suwitdi Kusumo Dilogo Soeroto. (2017). judul buku: Menjadi Pemimpin yang melayani menyandingkan Etos Spiritual untuk membangun Karakter Pemimpin yang melayani. Vertical Grafika Yogyakarta.

Tambunan, F. (2019). Karakter

Kepemimpinan Kristen Sebagai

Jawaban Terhadap Krisis
Kepemimpinan Masa Kini. Illuminate. Tanyid, M. (2018). Kualitas Pemimpin Sebagai Pendidik Dalam Menghadapi Konflik. BIA': Jurnal Teologi Dan Pendidikan Kristen Kontekstual. https://doi.org/10.34307/b.v1i1.24 Tari, E., Mosooli, E. A., \& Tulaka, E. E. (2019). Kepemimpinan Kristen Berdasarkan 1 Timotius 3:1-7. Jurnal Teruna Bhakti.

Tomatala, Y. (2006). Kepemimpinan Yang

Dinamis (Aspek-Aspek Dalam

Kepemimpinan). gandum mas.

Tomatala, Yakob. (2003). Teologi Misi. YT

Leadership Foundation.

Zaluchu, S. (2018). Respons Tests of

Leadership Menurut Teori Frank

Damazio Pada Mahasiswa Pascasarjana Jurusan Kepemimpinan Kristen STT Harvest Semarang. In Jurnal Jaffray

(Vol. 16, Issue 2, p. 145).

https://doi.org/10.25278/jj71.v16i2.289

Zaluchu, S. E. (2020). Strategi Penelitian

Kualitatif dan Kuantitatif Di Dalam

Penelitian Agama. Evangelikal: Jurnal

Teologi Injili Dan Pembinaan Warga

Jemaat, 4(1), 28-38.

https://doi.org/10.46445/ejti.v4i1.167 